\title{
"MENJADI INDONESIA" DI TAHUN 1950-AN: SAUTI, TARI SERAMPANG XII, DAN KEBANGKITAN MELAYU DI SUMATRA UTARA ${ }^{1}$
}

\author{
"BECOMING INDONESIA" IN 1950s: \\ SAUTI, SERAMPANG XII DANCE, \\ AND MALAY'S AWAKENING IN NORTH SUMATRA \\ Nasrul Hamdani \\ Balai Pelestarian Nilai Budaya Aceh \\ Jln. Twk. Hasyim Banta Muda No. 17 Mulia, Banda Aceh 23123, Indonesia \\ noharahap@gmail.com
}

Diterima tanggal 27 Februari 2020

Disetujui tanggal 18 Mei 2020

\begin{abstract}
In Indonesian history, 1950-1963 was labeled the most dynamic period. At the time, the national integration that was represented by the term of Berdikari (acronym from berdiri di atas kaki sendiri) as an "ideology" for forming national economic, nationalizing foreign company, and subdueing local rebellions took shape. In this process, the role of cultural activists even became more important, especially in their efforts to represent local culture at the national level, while they were challenged by central and local conflict of interests at the same time. By taking Sauti, one of these Malay cutural activists, as a case study, this research aims to understand Sauti's struggle in representing Malay culture, especially the dance of Serampang XII as a product of "national culture". By implementing historical method, data were acquired mainly by documentary sources and in-depth interviews. This research indicates that the role and contribution of Sauti were decisive in promulgating Serampang XII. Nevertheless, he faced some challenges from Malay people and the Malay Sultanate which claimed itself as the owner of Malay great tradition.
\end{abstract}

Keywords: Malay, Sauti, Malay performing arts, and 'becoming Indonesia'.

\begin{abstract}
ABSTRAK
Dalam sejarah Indonesia, tahun 1950-1963 disebut sebagai periode paling dinamis. Pada masa ini, integrasi nasional yang dilandasi asas Berdikari (akronim dari berdiri di atas kaki sendiri) sebagai "ideologi" utama dalam pembentukan ekonomi nasional, menasionalisasi perusahaan asing, dan menumpas pemberontakan daerah mulai terbentuk dengan jelas. Dalam proses ini, peran penggiat kebudayaan daerah menjadi penting terutama dalam usaha-usaha merepresentasikan daerah di tingkat nasional, sementara pada saat yang sama berhadapan dengan konflik kepentingan antara pusat dengan daerah. Dengan mengambil Sauti, tokoh penggiat kebudayaan Melayu, penelitian ini bertujuan memahami perjuangan Sauti dalam

1 Risalah ini pernah disampaikan dalam Seminar Nasional Hasil Penelitian Balai Pelestarian Sejarah
dan Nilai Tradisional (BPSNT) se-Indonesia, Bandung, 9-12 Juli 2012; belum pernah diterbitkan.
\end{abstract}


merepresentasikan kebudayaan Melayu sebagai produk "Kebudayaan Nasional”. Dengan pendekatan sejarah, sebagian besar data diperoleh melalui sumber-sumber dokumentasi dan wawancara mendalam. Penelitian ini ingin menunjukkan peran dan kontribusi Sauti yang menentukan dalam penyebarluasan Serampang XII. Namun dalam upaya itu, ia menghadapi tantangan dari sesama orang Melayu dan kesultanan Melayu yang menganggap dirinya sebagai pemilik kebudayaan besar Melayu.

Kata kunci: Melayu, Sauti, seni pertunjukan Melayu, dan 'menjadi Indonesia'.

\section{A. PENDAHULUAN}

Integrasi nasional, diiringi penguatan semangat untuk mandiri dengan jargon Berdikari (berdiri di atas kaki sendiri), menjadi ciri penting kebijakan Indonesia selama periode 1945-1949. Jargon penuh semangat ini kelak mendorong kesadaran baru dan mendasari kebijakan nasional sepanjang 1950-1965, mulai dari program Ekonomi Benteng, nasionalisasi perusahaan Belanda yang oleh Sutter dalam Kerkhof 2005:181 disebut Indonesianisasi, operasi penumpasan pemberontakan daerah, inisiasi New Emerging Forces bagi dunia, serta gagasan pembentukan Kebudajaan Nasional. Rangkaian kebijakan nasional itu terhubung dan kelak menjadi kata kunci untuk merekonstruksi rentetan peristiwa pada periode paling dinamis dalam sejarah Indonesia (Vickers 2008:67-68).

Satu peristiwa penting dan berdampak luas bagi kegiatan kebudayaan hingga kini ialah wacana pembentukan dan aktualisasi wacana Kebudajaan Nasional. Wacana yang diinisiasi sastrawan lintas ideologi yang kelak dikenal sebagai Angkatan '45 ini melalui "Surat Kepercayaan Gelanggang” (SKG) menjadi landasan sejarah, politik, sekaligus ideologis dalam proses perumusan Kebudayaan Nasional (Lindsay dan Liem 2011).

Pandangan teoretik dan empirik mengenai wacana pembentukan dan aktualisasi Kebudayaan Nasional ini cenderung direpresentasikan pada dinamika di Jakarta serta "pertarungan" antara Lembaga Kebudajaan Rakjat (Lekra) yang berpaham realismesosialis dan condong pada Partai Komunis Indonesia (PKI) dengan sastrawan dan seniman di luar Lekra yang menandatangani risalah Manifes Kebudajaan (Moeljanto 1995; Supartono 2000). Oleh penggiat Lekra, nama Manifes Kebudajaan ini disingkat secara agitatif sebagai Manikebu atau manikebo yang merujuk pada "air mani kerbau".

Pertarungan Lekra dengan Manikebu ini entah mengapa telanjur jadi representasi utama dalam narasi sejarah kebudayaan dalam periode 1950-1965. Padahal "pertarungan" itu baru benar-benar terjadi pada 1963, tidak lama setelah risalah Manifes Kebudayaan dimuat dalam Berita Republik dan Sastra pada Oktober 1963 (Moeljanto 1995) atau sekira tiga belas tahun setelah pernyataan SKG. Pemuatan empat poin Manifes penggiat 
kebudayaan non-Lekra itu langsung membelah seniman dan sastrawan atau siapapun penggiat kebudayaan masa itu secara vis-à-vis.

Penting untuk diketahui, bahwa para penandatangan SKG yang dipandang monumental oleh kalimat "Kami adalah ahli waris yang sah dari kebudayaan dunia dan kebudayaan ini akan kami teruskan dengan cara kami sendiri" adalah Asrul Sani (kelak mendirikan Lembaga Seniman Budayawan Muslim Indonesia atau Lesbumi pada 1962), Sitor Situmorang (kelak mendirikan Lembaga Kebudajaan Nasional/LKN), Rivai Apin, Basuki Resobowo, dan Pramoedya Ananta Toer. Tiga orang terakhir ini kemudian menjadi tokohtokoh Lekra yang berpengaruh besar (Lindsay 2011a:6,12-14). Namun setelah Oktober 1963, Asrul Sani dan Sitor Situmorang bersimpang jalan dengan Rivai Apin, Basuki Resobowo, dan Pramoedya Ananta Toer.

Perhatian pada pertarungan LekraManifes Kebudayaan serta polarisasi akibat pertarungan itu membuat peristiwa kebudayaan lain terutama perkembangan budaya pop yang berlangsung antara 1950-1963 luput dari perhatian. Satu alasan mengapa perkembangan kebudayaan masa itu berpusar pada satu poros ialah karena tokoh-tokoh dua kelompok penggiat kebudayaan itu menaruh perhatian dan berkonsentrasi pada dua bidang yang sama, yaitu sastra dan seni rupa. Dua bidang ini (lebih) dipandang sebagai arena budaya tinggi (Lindsay 2011a:6).
Hal ini menjelaskan mengapa seranganserangan Lekra yang disokong penguasa tertuju para sastrawan, seniman dan/atau para penulis dari kelompok Manifes Kebudayaan seperti H.B. Jassin, Hamka, Taufik Ismail, Sutan Takdir Alisjahbana, dan Idrus.

Dalam skala daerah, pertarungan kebudayaan yang identik dengan pertentangan dua ideologi di Jakarta itu tidak secara langsung mempengaruhi wacana dan penggiat kebudayaan di daerah karena keduanya cenderung menggarap "budaya tinggi" yang bukan ranah garapan penggiat kebudayaan daerah. Salah satu sebab lain mengapa jalannya pertarungan itu juga agak diabaikan di daerah terutama Sumatra Utara ialah "buat kebanyakan warga Medan, Singapuralah yang merupakan Pusat kebudayaan, bukan Jakarta" (Plomp 2011:435).

Dari Singapura, orang di Medan dan Sumatra Utara umumnya dapat menikmati musik, lagu, dan lakon pesohor seperti P. Ramlee, Ahmad CB, atau Kasma Booty dalam tayangan film terbaru produksi Singapura, Amerika Serikat atau Hongkong di bioskopbioskop yang tumbuh pesat ketika Lekra dan kelompok Manifes Kebudayaan terus berkubang dalam perdebatan sengit menyoal sari Kebudayaan Nasional Indonesia apakah meninggikan tradisi lama atau mengikuti modernisasi.

Dari Singapura ini pula, seniman Medan dapat mengembangkan rumah produksi dengan kualifikasi baik untuk memenuhi kebutuhan bioskop hingga 
memasuki senja kala awal 1980-an.

Film pertama yang diproduksi dari kota ini ialah "Kuala Deli" (1954). "Serampang 12" (1956) yang dibintangi R. Ismail, Wolly Sutinah, dan Aminah Cendrakasih diproduksi Radial Film ketika tari pergaulan Melayu asal Perbaungan itu mencapai puncak popularitasnya.

Penanda lain betapa polarisasi kebudayaan di Jakarta itu tidak berpengaruh secara langsung ialah "tidak semua orang di Medan (mau) menerima otoritas mereka yang menyebut diri pemimpin budaya di Jakarta" (Plomp 2011:429). Pandangan orang di Medan dan kemungkinan daerah-daerah lain di Sumatra Utara pada otoritas di "pusat" merupakan sedikit sifat warisan para Deliaan (orang Belanda-Deli atau Eropa-Deli) sifatnya kasar, dan pemabuk. Para Deliaan ini mengganggap lebih pantas menghormati Direktur Deli Mij. yang rutin membagikan tantieme (bonus) dalam jumlah besar dan cuti tahunan berbayar ke Eropa daripada Gubernur Jenderal Hindia Belanda di Batavia (Breman 1997:198-99; Reid 1987:78).

Hamka yang memulai karir kepenulisannya di Medan pada masa kolonial lalu pindah ke Jakarta juga pernah mempertanyakan status Jakarta sebagai pusat kebudayaan Indonesia. Selain itu, di Medan "hampir-hampir tidak ada pasar untuk karya-karya sastra Indonesia modern yang 'serius", (Plomp 2011:418,427). Karya "sastra" yang laris di kota perkebunan ini ialah roman picisan yang berkembang sejak 1930-an mengiringi surat kabar dan bisnis percetakan. Cerita roman ini biasanya bertema cinta, seks, perampokan, pembunuhan, dan penyelundupan berbahasa Melayupasar sehingga dianggap karya sastra rendah, serendah harganya.

Dikotomi antara pusat dan daerah (termasuk permasalahan etnisitas di daerah) juga menjadi alasan mengapa kebijakan Jakarta serta apa yang terjadi di sana tidak mudah diterima sebagai model di Sumatra Utara. Dikotomi ini terus menguat meski semula cenderung menjadi konsumsi elite politik sejak perang kemerdekaan dan memuncak pada akhir 1950. Selama perang kemerdekaan saja daerah ini telah dilanda perpecahan internal terutama karena lemahnya pengaruh pemerintah pusat sehingga revolusi kemerdekaan yang berlangsung di sini berjalan sepotong-sepotong (Ricklefs 2005:403). Hal itu masih ditambah oleh kenyataan geopolitik bahwa daerah Republik bahkan hingga 1957 masih terbatas pada Jawa dan sebagian Sumatra saja (Asnan 2007; Bahar 2018; Cribb 1990; Kahin 2008).

Oleh sebab itulah, gagasan unifikasi dan integrasi sepanjang 19501965 terus dikampanyekan dari Jakarta dan cabang-cabang organisasi politik di daerah sebagai gerakan untuk mencapai tujuan, mulai dari menghapus pemerintah swapraja Daerah Istimewa Sumatra Timur (DIST) yang sedang gencar diajukan, hingga kampanye ke negara-negara bagian Republik Indonesia Serikat 
untuk kembali ke negara kesatuan. Inilah landasan mengapa terma "menjadi Indonesia" yang digunakan oleh beberapa sejarawan dan penulis sejarah dalam historiografi Indonesia pada awal aras baru lebih populer terutama untuk membangkitkan kesadaran sejarah bahwa "kesalahan di masa lalu tidak boleh terulang lagi" (Lindsay 2011b; Simbolon 2007; Suprayitno 2001).

Terma "menjadi Indonesia" juga menjadi isu kebudayaan yang menarik perhatian dan aktual sepanjang dasawarsa penulisan ini (Lindsay 2011b:245-46). Dalam risalah ini, "menjadi Indonesia" merupakan isu kebudayaan awal yang tumbuh dan mengakar lebih dahulu sekaligus inheren dengan gagasan negara kesatuan. Oleh sebab itu, konteks "menjadi Indonesia" ini pernah dipahami sebagai kebudayaan kesatuan (Kleden 1987:217). Sebagai isu kebudayaan, terma kembali "menjadi Indonesia" menguat sejak awal 1960 ketika Jakarta mulai berhadapan dengan pemberontakan daerah, masalah ekonomi, aksi Belanda di Irian Barat serta aksi "neokolonialisme" Inggris di Malaya hingga pembentukan Malaysia. Sepanjang periode itu hingga kini, isu "menjadi Indonesia" dalam skala Sumatra Utara telah digunakan untuk membangkitkan kesadaran, memberi ilham sekaligus corak baru pada pembentukan konsep atau gagasan (kelompok etnik) Melayu di Indonesia yang tidak lagi memiliki orientasi kultural karena ketiadaan Sultan terutama untuk membangun konstruk "Melayu Indonesia". Konstruk ini dapat dibangun sebagai antitesis konstruk Melayu-politik Malaysia yang menyatakan bahwa Malaysia merupakan model negeri Melayu ideal setelah negeri itu berhasil merumuskan dan menerapkan konsep Ketuanan Melayu sebagai landasan penyelenggaraan negara Melayu modern dan representasi politik kawasan (Andaya 2006:73). Dalam urusan ini, elite Sumatra Timur sudah lebih dahulu menuntut pembentukan DIST sebagai langkah memulihkan kedudukan politik dan membangun konstruksi Melayu-politik Indonesia.

Konstruksi di atas dapat dipandang selaras dengan rentetan peristiwa yang membingkai these "Kebudajaan Nasional" dan pembentukan apa yang dinamai kepribadian bangsa. Kebudayaan Nasional meskipun tidak pernah didefinisikan secara jelas atau digarap secara ilmiah (Kleden 1987:232-33), konsep ini diberi pengertian sebagai suatu bentuk kebudayaan baru yang mencerminkan kepribadian bangsa. Pengertian yang tidak cukup jelas konsep maupun operasionalnya ini dengan mudah dijadikan hujah bahkan ideologi politik penguasa beserta pendukungnya untuk menghabisi siapa saja yang beroposisi (Kleden 1987:226-27). Dalam konteks peristiwa ini, sang pendukung itu adalah kelompok kebudayaan Lekra yang secara eksplisit memberi pertimbangan kritis pada kedudukan tradisi dan kelampauan dalam 
pembentukan kebudayaan nasional melawan kelompok Manifes Kebudayaan, pengkritik sikap dan kebijakan kebudayaan pemerintah.

Dalam perkembangannya, pengertian "Kebudajaan Nasional" itu juga diberi pengertian tambahan bahwa "kebudayaan nasional adalah puncakpuncak kebudayaan daerah" yang mulai menempatkan daerah sebagai bagian integral dalam proses sekaligus "ajakan" Jakarta pada daerah untuk mulai mengintegrasikan bagian-bagian kebudayaan yang sama dari daerah dan merepresentasikannya sebagai kebudayaan nasional (dari) Indonesia. Oleh sebab itu, dalam konteks ajakan ini Jakarta boleh dibilang hampir mengakomodasi seluruh daerah sebagai bagian penting untuk merealisasikan gagasan dan bentuk baru kebudayaan yang merepresentasi negara kesatuan dan kepribadian bangsa itu.

Wacana pembentukan "Kebudajaan Nasional" ini sesungguhnya telah dianggap sebagai "ajakan" yang berhasil membangun suatu kesadaran integrasi seperti yang diinginkan Sukarno setelah membubarkan Konstituante. Kesadaran ini berhasil membangun nalar, semangat, dan pemahaman baru bagi pemikir, penggiat, dan pelaku kebudayaan di seluruh Indonesia untuk bergerak secara otonom karena Jakarta telah memberikan suatu kesempatan dan pengalaman bagi para maestro dan penggiat kebudayaan daerah untuk berperan dan terlibat dalam suatu suasana festive yang difasilitasi pemerintah dalam rangkaian kegiatan bergengsi yang dinamai Misi Kebudayaan Indonesia selama 19531965.

Misi bergengsi ini tidak saja memberikan kesempatan dan pengalaman pentas di panggung dunia pada seniman daerah tetapi menghubungkan Indonesia dengan dunia luar dalam arti sebenarnya. Menurut Lindsay dan Liem, pengalaman itu "memberikan suatu pengalaman bersama yang menyediakan suatu cara untuk berbicara satu sama lain mengenai seni dan bangsa, pengalaman perbandingan yang mendorong mereka untuk berpikir tentang kesenian di Indonesia dalam kerangka nasional" (Lindsay 2011b:250).

Pandangan, pemikiran, pemahaman yang memberi pengalaman baru itu juga dirasakan sejumlah penggiat kebudayaan Melayu dan orang Melayu di Sumatra Utara. Pengukuhan Serampang XII, tari kreasi Melayu gubahan Sauti dari Perbaungan, kota di Kabupaten Serdang Bedagai masa kini sebagai tari nasional oleh Presiden Sukarno berhasil membentuk suatu kesadaran dan semangat yang dipandang sebagai titik awal kebangkitan Melayu yang tidak memiliki raja sejak Revolusi Sosial 1946. Pembentukan kesadaran dan semangat baru itu mendorong orang Melayu untuk kembali turut dalam proses panjang "menjadi Indonesia" setelah "kalah" dua kali. Kekalahan pertama dikaitkan dengan Revolusi 
Sosial yang menghancurkan hegemoni dan kekuasaan para sultan dan raja di Sumatra Timur meski para penguasa tradisional itu sudah menyatakan berdiri bersama Indonesia dan mengusulkan pembentukan DIST.

Kegagalan kedua orang Melayu itu dihubungkan dengan pendirian Negara Sumatra Timur (NST), negara bagian masa Republik Indonesia Serikat (RIS) yang didirikan oleh tiga kelompok elite penduduk asli Sumatra Timur yaitu perwakilan dari kelompok etnik Karo dan Simalungun (Suprayitno 2001:89,101). Negara Sumatra Timur yang dipimpin Tengku Mansur, seorang Pangeran Asahan terkemuka sekaligus salah satu pendiri Jong Sumatranen Bond ini, menjadi negara bagian yang paling panjang umurnya. NST terbilang makmur dan sukses untuk sebuah federasi seumur jagung sebelum dipaksa bubar dan dilebur dalam Republik Indonesia dalam provinsi baru bernama Sumatra Utara yang merupakan penggabungan daerah bekas Residensi Sumatra Timur dan Residensi Tapanuli yang kontras. Perbedaan mencolok itu terlihat jelas dari dikotomi Melayu dan Batak, these yang relevan untuk menjelaskan kontras dua kebudayaan nominal di Sumatra Utara itu secara historis, politik, dan kultural hingga kini (Perret 2010:55-73).

Untuk mendapatkan suatu gambaran mengenai hubunganhubungan antara Sauti, kisah hidup maestro Melayu ini dengan rangkaian peristiwa kebudayaan yang berlangsung dalam periode penulisan ini dengan proses "menjadi Indonesia" sepanjang dasawarsa tahun 1950-an itu kami merumuskan tiga pertanyaan pokok.

1. Bagaimana kisah hidup Sauti dan keadaan lingkungan yang menempa kehidupannya sehingga menjadi tokoh seniman Melayu?

2. Bagaimana peran dan kontribusi Sauti dalam merepresentasikan kesenian Melayu di Indonesia dan Sumatra Utara hingga menjadi produk Kebudayaan Nasional?

3. Hambatan dan tantangan apa yang dihadapi Sauti dalam merepresentasikan diri, produk kebudayaan Melayu di Indonesia?

Penulisan biografi Sauti ini bertujuan untuk "menghidupkan" kembali sosok maestro yang menjadi representasi tokoh dan kebudayaan Melayu pada masa itu. Selain itu, rekonstruksi kisah hidup maestro yang pernah dijuluki Dada Meuraxa, penulis Medan berdarah Aceh sebagai Fred Astaire dari Serdang (Meuraxa 1956) ini ialah memahami motivasi Sauti selama menjaga kesinambungan dan menggembirakan kesenian Melayu melalui Serampang XII pada dua panggung sekaligus, panggung politik di kalangan seniman di Sumatra Utara dan panggung kebudayaan nasional selama 1950-1963 dari perjalanan tim Misi Kebudayaan Indonesia ke penjuru dunia.

Kisah hidup Sauti juga berhubungan erat dengan jawaban atas pertanyaan bagaimana tari kreasi Melayu pengganti dansa yang 
digubahnya itu dikonstruksi lalu didaulat sebagai produk kebudayaan nasional. Bagaimana tari pergaulan itu diajarkan luas ke seluruh Indonesia lalu menjadi milik bersama seluruh orang Indonesia sebelum mengalami pergeseran substansial akibat perbedaan pandangan terutama dalam menempatkan status kepemilikan serta hak untuk mengembangkan seni pertunjukan Melayu justru di tempat Sauti berkarya.

Biografi Sauti ini juga menjadi antitesis biografi politik, kisah hidup tokoh dari golongan elite dan/atau perjuangan tokoh militer yang kerap direkonstruksi sebagai bagian dari sejarah besar untuk mengisi celah-celah kosong dalam historiografi Indonesia sesudah 1967 (Klinken 2007:197-214).

Biografi Sauti juga dapat dimanfaatkan sebagai kisah teladan maupun nilai baik yang mengilhami sekaligus landasan moral untuk merevitalisasi nilai-nilai dan kebanggaan "menjadi Indonesia" di masa lalu yang juga kompleks permasalahannya untuk menjawab tantangan masa kini dan nanti.

\section{B. METODE}

Penulisan kisah hidup Sauti serta peristiwa yang melingkungi pengubah Serampang XII ini disusun dengan metode sejarah. Sumber sejarah lisan menjadi data utama untuk merekonstruksi kisah hidup Sauti di samping sumber tertulis yang dihimpun sebelum dan selama penelitian naskah ini berlangsung. Sumber lisan berupa kenangan dan pandangan tentang Sauti diperoleh melalui serangkaian wawancara dengan orang-orang yang mengenal Sauti secara pribadi ditambah keterangan tambahan dari pihak lain yang mengetahui sosok Sauti meski tidak pernah berinteraksi langsung. Cerita tentang Sauti yang bersumber dari wawancara didokumentasikan selama April-Mei dan Juli-Agustus 2012 di Medan dan Perbaungan.

Portrayal menjadi model pilihan untuk merangkai kisah hidup Sauti (Kuntowijoyo 2003:206). Model pengkisahan ini digunakan untuk memotret dan menggambarkan dunia sang tokoh utama dengan pendekatan sejarah. Oleh karena itu, rekonstruksi kisah hidup Sauti, orang biasa yang mempengaruhi peristiwa ini, tidak saja menggambarkan prestasi sang tokoh semata tetapi juga turut menggambarkan hubungan Sauti dengan tokoh lain yang menjadi sekondan atau kontestannya. Kisah hidup Sauti ini juga dihubungkan serta peristiwa dalam satu latar sejarah, seperti menghubungkan kisah Sauti dan Serampang XII gubahannya itu dengan dinamika berkesenian selama gagasan "Kebudayaan Nasional" yang sedang didengungkan dari Jakarta.

Portrayal mengandung dan mengemban nilai sejarah yang jika dikemas baik dapat berdampak luas. Dalam kisah hidup Sauti, nilai sejarah itu adalah menghidupkan kembali gagasan aktual dari masa lampau seperti "menjadi Indonesia" 
yang memang harus terus menerus digaungkan. Selain itu, pembelajaran tentang keteladanan, kesederhanaan, tanpa pamrih, kerendahan hati, dan etos kerja Melayu yang secara langsung maupun tidak langsung melekat pada sosok Sauti.

Selain gagasan "menjadi Indonesia" itu, masalah-masalah yang berkaitan dengan Serampang XII seperti klaim produk budaya, pergeseran teknik, cerita serta pemahaman sejarah atasnya yang beragam itu merupakan dampak langsung dari ketiadaan biografi Sauti. Dalam konteks ini, biografi Sauti adalah penjelasan pokok pangkal dan seluk beluk Serampang XII.

\section{HASIL DAN BAHASAN \\ 1. Sauti dan Kisah Hidupnya}

Sauti lahir pada 16 Juni 1903 di Pantai Cermin, sebuah pekan 'kota kecil yang menjadi pusat pasar mingguan' berjarak kira-kira 20 kilometer dari Perbaungan, ibu kota Kesultanan Negeri Serdang sejak 1889. Ayah Sauti bernama Tatih, ibunya bernama Semah. Sang ayah meninggal dunia tidak lama setelah ia lahir. Oleh karena itu, tidak banyak keterangan tentang ayahnya ini. Orang tua Sauti itu berasal dari Pantai Cermin, yang merupakan kampung halaman Sultan Sulaiman Shariful Alamshah, sultan Melayu di Sumatra Timur yang paling panjang masa pemerintahannya sekaligus yang "rewel" dan tidak mudah dibujuk (Reid 1987:88,100,137).
Kisah Sauti yang dianugerahi kepandaian bermusik, menari, dan mendidik dimulai dari pilihan ibunya yang menolak ganti tikar ${ }^{2}$ sampai akhir hayatnya. Semah memutuskan pindah ke Perbaungan untuk mengabdi di Istana Darul Arif, Kotagaluh. Oleh salah satu cucunya diceritakan, Semah yang masa nifasnya belum berakhir membawa bayi Sauti menumpang kereta lembu dari Pantai Cermin ke Perbaungan. ${ }^{3}$

Di Istana Darul Arif, Semah diterima menjadi dayang istana Serdang. Tidak diketahui bagaimana Semah memasuki lingkungan istana itu tetapi hubungan sekampung-halaman dengan sultan dan ibundanya menjadi alasan paling mungkin. Selain itu, sebagai perempuan Melayu yang ditinggal mati suami, Semah merasa harus meminta perlindungan sultan. Bagi rakyat Melayu, dapat mengabdikan diri di istana sebagai dayang ataupun boy untuk melayani sultan merupakan kebanggaan tersendiri. Selain mengangkat derajat hidup, kawula Melayu yang mengabdi di istana memperoleh kemudahan yang belum tentu diperoleh kawula Melayu biasa yang tinggal di luar istana (Agustono 1993:59-60). Kemudahan inilah yang diperoleh Semah hingga anaknya Sauti dapat mengecap

\footnotetext{
2 Ganti tikar adalah adat perkawinan Melayu berupa pernikahan dengan kakak atau adik pasangan (suami/istri) yang meninggal.

${ }^{3}$ Wawancara, Makmur Sauti, Medan, 4 Maret 2012.
} 
pendidikan formal dan menjalin hubungan dengan elite istana termasuk orang-orang penting di luar istana.

Di Istana Serdang itulah Sauti kecil berkenalan dengan kegiatan kesenian yang mendorong bakatnya tumbuh. Sejak akhir abad ke-19, Serdang telah dikenal dan menjadi ruang tempat tumbuh kembang seni pertunjukan kontemporer Melayu. Opera Bangsawan yang dikenal dengan sebutan stamboel dan/atau bangsawan konon bermula dari negeri ini pada 1895, didirikan oleh Sultan Sulaiman (Perret 2010:349). Stamboel yang dinamai Seri Indian Ratu ini disebutkan berkembang dan menyebar ke seluruh Hindia Belanda dan Semenanjung lalu kembali lagi ke tempat asalnya di Sumatra Timur ketika kemunduran mendera kelompok sandiwara keliling ini (Hamdani 2011:30-31). Serdang juga menjadi ruang bertumbuh bagi kelompok musik Brass Band yang tengah populer, ronggeng serta seni pertunjukan persilangan budaya seperti zapin, makyong, calti, dan gambus. Di Serdang, ragam kesenian itu berkembang pesat hingga identik dengan negeri itu. Dari istana dan suasana negeri inilah bakat dan kegemaran Sauti pada kesenian terutama musik dan tari tumbuh dan berkembang.

Perkembangan kesenian di Serdang ini tidak dapat dilepaskan dari peran Sultan Sulaiman yang menaruh perhatian penuh dan minat yang besar pada kesenian sejak berkuasa pada 1879-1946. Sultan Sulaiman mewajib- kan putra-putrinya belajar dan berlatih memainkan alat musik, menyanyi, atau menari di istana, selain kewajiban mengikuti pendidikan formal. Putra Mahkota Serdang, Tengku Rajih Anwar, misalnya. Ia dikenal sebagai pesilat, pemain sepak bola juga peronggeng dan penggubah tari berbakat. Bahkan salah satu istrinya adalah penari. Kakak, adik, anak, dan kemenakan Anwar juga memiliki keahlian masing-masing dalam menari, menyanyi dan/atau memainkan alat musik. Adiknya, Tengku Luckman Sinar dijuluki Si Kijang Lincah karena aksi khas ketika memainkan teknik lompat kijang dalam Serampang XII selain mahir menabuh perkusi (Hamdani 2012:26-33). ${ }^{4}$ Pun demikian dengan anak Anwar, Tengku Sitta Syaritsa. Sitta kelak dikenal sebagai penari, pengajar tari, dosen etnomusikologi Universitas Sumatra Utara, serta vokalis bagi dua kelompok band keluarga Serdang bergaya Hawaiian yang populer di Medan pada 1960-an, yaitu Sircombo (sic mungkin juga nama kelompok ini adalah SIR Combo, singkatan dari Seri Indera Ratu yang memang berasal dan sebagian besar terdiri atas orang asal Serdang) dan Tropicana. ${ }^{5}$

Perhatian, minat dan dukungan Sultan Sulaiman pada kesenian membuat Serdang menjadi tempat ideal bagi pekerja dan penggiat kesenian

\footnotetext{
${ }^{4}$ Wawancara, Tengku Daratul Qamar, Medan, 6 Maret 2012.

5 Wawancara, Tengku Mira Sinar, Medan, 7 Maret 2012
} 
hingga sang sultan didaulat sebagai mecenas (sponsor kegiatan kesenian) jauh setelah mangkat (Ratna 2012:65). Sultan Sulaiman yang sering bersilang pendapat dengan kebijakan dan pandangan pejabat kolonial ini juga melindungi dan mensponsori Opera Bangsawan Seri Indera Ratu yang redup pada awal abad ke-20 bersamaan dengan kelompok opera terkemuka lainnya. Sultan yang gemar memainkan biola dan memiliki sejumlah biola seperti biola Stradivari ini juga mendirikan Brass Band Sultan Serdang sebagai kelompok musik kerajaan sekaligus untuk pertunjukan (Ratna 2012:57-65). Kelompok yang dicirikan dengan penggunaan alat-alat musik berbahan kuningan dan tengah populer masa itu dipimpin Tengku Munzir, kemenakan Sultan Sulaiman. Kelompok Brass Band Sultan Serdang ini berlatih sekali setiap dua minggu di rumah pemimpin sekaligus konduktornya yang masih berada di lingkungan istana.

Di lingkungan istana inilah, Sauti tumbuh bersama kegemaran penghuninya pada musik, tarian, dan nyanyian. Oleh sebab itu, kemahiran Sauti memainkan sejumlah alat musik, menata komposisi, membaca, dan menulis partitur lagu tidak lepas dari keadaan di lingkungan istana yang dibumihanguskan pada 1947 ini. Belum diketahui sekolah dasar apa yang dijalani Sauti tetapi jika merujuk jumlah sekolah Melayu atau disebut Sekolah Kelas Tiga yang didirikan Sultan Sulaiman sejak 1911 (Ratna
2012:53-54) di Simpang Tiga, Galang, Petumbukan, Rantau Panjang, Tanjung Morawa, Dalu X, Batang Kwis, Serbajadi, Silandak, Gunung Paribuan, Gunung Meriah, Tiga Juhar, Rambei, Durian Tinggung, Gunung Rinteh, Tadukan Raga, Pantai Cermin, Araskabu, Ramunia, Bandar Gubung, Kotarih dan Sennah, kemungkinan Sauti merupakan alumni sekolah Melayu di Simpang Tiga yang tidak jauh dengan Istana Serdang.

Pada usia 18 tahun, Sauti berhasil mendapatkan ijazah Normaalschool voor Inland Hulponderwijs sehingga dapat langsung ditugaskan sebagai guru bumiputra untuk mata pelajaran kesenian di salah satu sekolah di Pematang Siantar. Jabatan guru inilah yang membuat Sauti dikenal pula dengan nama Guru Sauti atau Engku Sauti. Engku ini merupakan gelar yang harus disebutkan dengan hormat oleh murid-muridnya termasuk anak-anak bangsawan Serdang yang diajarnya.

Pada 1926, Sauti dipindahkan ke Inlandschool di Sunggal. Pada usia 24 tahun, Sauti kembali ke sekolah tempat ia belajar semasa kecil dahulu di Perbaungan sebagai Kepala Sekolah Gouvernement Inlandschool. Kepindahan Sauti ini menjadi titik kisar penting dalam karir keseniannya sebab ia dekat kembali dengan Pantai Cermin, kampung halaman yang mengilhami sejumlah karya-karya terutama musik dan lagu pengiring tarian. Karir Sauti sebagai guru di masa kolonial itu terhenti ketika Jepang menduduki Sumatra Timur. Ketika itu, Sauti 
tengah mengemban jabatan Kepala Vervolgschool atau Sekolah Sambungan II untuk alumni sekolah bumiputra yang ingin melanjutkan pelajaran ke sekolah guru di Medan sejak 1941 (So’uyb 1989:63).

Ketika Indonesia merdeka, Sauti kembali menjadi guru. Ia mengajar di Medan, namun tetap berdomisili di Perbaungan. Tidak lama berselang, antara 1946-1950 Sauti yang mulai memasuki usia pensiun diangkat menjadi schoolopziener (penilik sekolah) untuk sekolah-sekolah di wilayah Serdang, Padang, dan Bedagai yang berkedudukan di Perbaungan. Jabatan ini membuat Sauti tetap dekat dengan ibunya yang kian renta. Pada 1951, Sauti diperbantukan sebagai guru pada Jawatan Pendidikan, Pengajaran, dan Kebudayaan Provinsi Sumatra Utara hingga memasuki usia pensiun. Selama bekerja di jawatan yang mengelola Gedung Kesenian di Jalan Bali (sekarang Jalan Irian Barat) dekat Stasiun Besar Medan inilah, Serampang XII yang digubah Sauti sejak awal 1930-an mulai menapak perkembangan pesat hingga ke panggung pertunjukan dunia.

Sejak Sauti diperbantukan pada jawatan itu, panggung untuk Serampang XII terbentang luas. Pada tahun Sauti bertugas di jawatan Kebudayaan, tari itu tampil di hadapan Presiden Sukarno, lalu Yayasan Budaya Medan (1952), Konferensi Jawatan Kebudayaan se-Indonesia, Pembukaan Pekan Olahraga Nasional (PON) III di Medan dan Beijing (1953), Peringatan Kemerdekaan ke-9 dan Kongres Bahasa (1954), Eropa Timur (1955-1956) hingga terbit film bertajuk “Serampang 12" (So'uyb 1989:57-58).

\section{Sauti, Adram, dan Anwar}

Pada 1949, Sauti membakukan pola lantai dan pola udara seluruh tari gubahannya termasuk Serampang XII dan menghimpunnya dalam satu buku catatan yang disalin untuk pegangan sida atau lekun; mereka yang belajar dan mengajarkan tari. Menurut Sauti, langkah ini penting sebagai usaha menjaga keaslian tarian lincah dengan rentak cepat dari Serdang (Nurwani 2003:45) sekaligus bukti penciptaan tari itu. Namun ketika tari pergaulan yang memikat itu mulai menjadi bagian kegiatan kesenian anakanak bangsawan Serdang sejak awal 1950, Istana Serdang disebutkan "mengambil" langkah untuk "menata" dan "memperbaiki" tari gubahan Sauti yang pernah dipertontonkan dalam acara amal pada 1938 mewakili Serdang di Medan agar sesuai dengan adat resam Melayu (Nurwani 2003:51-52). ${ }^{6}$

Waktu itu, Kepala Rumah Tangga Kesultanan Serdang, jabatan tidak resmi untuk Tengku Rajih Anwar dalam peran terbatas sebagai Sultan Kerajaan Negeri Serdang sejak 1946, meminta pandangan Sauti yang menggubahnya. Sauti berkenan dengan permintaan

6 Cerita serupa juga disampaikan oleh Yose Rizal Firdaus di Medan pada 10 Maret 2012. 
terutama agar tari itu bisa “disesuaikan”. Menurut Tengku Sitta Syaritsa putri Anwar, sang ayah menata kembali gerakan-gerakan dalam Serampang XII agar sesuai dengan adat resam Melayu. Penyesuaian itu disebutkan agar gerakan-gerakan seperti lenggok atau kerling tidak dilenggangkan secara berlebihan karena dapat menimbulkan hasrat (Nurwani 2003:45).

Permintaan Kepala Rumah Tangga Kesultanan Serdang itu bukan tanpa alasan. Sebagai penguasa Melayu sekaligus orang yang menaruh perhatian besar pada kesenian, Anwar sadar bahwa pemilik sesungguhnya kesenian Melayu adalah kawula. Masa itu, Anwar memerlukan tumpuan baru untuk membangun kembali hegemoni Serdang yang tidak lagi memiliki sultan definitif, seperti Tengku Osman yang memimpin Kerajaan Negeri Deli serta Tengku Saibun yang memimpin Negeri Asahan dengan status sultan.

Ketiadaan jabatan Sultan Serdang definitif itu selalu dikaitkan pada tiga hal, yaitu penetapan Anwar sebagai tronoopvolger (putra mahkota) pada 1918 merupakan kehendak Batavia sehingga Sultan Sulaiman memilih untuk menyerahkan urusan tertentu saja kepada Anwar.

Hal kedua ialah, Anwar memendam kekecewaan terhadap pemerintah dalam menangani kejahatan ketika revolusi sosial meletus. Oleh sebab itu, ia menolak menggantikan kedudukan Sultan Sulaiman sesudah mangkat. Bekas anggota Shu Sangi Kai Sumatra Timur ini memilih untuk menjadi Kepala Rumah Tangga seperti Tengku Atha'ar di Langkat, Negeri Melayu yang paling terdampak revolusi sosial.

Hal ketiga berkenaan dengan perjanjian utang piutang antara Sultan Serdang dengan Sultan Kutai antara 1934-1935. Reid memastikan perjanjian utang piutang itu benar adanya (Reid 1987:98), tetapi tidak diketahui apakah terdapat klausul yang menjelaskan kedudukan Anwar dalam perjanjian utang piutang antarpemerintah swapraja di Hindia Belanda itu.

Di lingkungan keluarga Serdang beredar cerita, Sultan Sulaiman "mengagunkan" jabatan Tengku Mahkota Serdang dalam perjanjian itu bahwa Anwar tidak akan bisa menjadi sultan sebelum utang pada Negeri Kutai dibayar lunas. Dalam versi lain tersebut, selama utang Serdang belum dilunasi, Serdang tidak akan pernah memiliki raja.

Hal ketiga inilah yang paling mungkin karena pelajar Middelbare Opleiding School voor Inlandsche Ambtenaren (MOSVIA) yang harus dipanggil pulang sebelum tamat ini dikenal sebagai sosok temperamental dan kaku dalam memegang prinsip. Barangkali inilah sebab mengapa Anwar menolak pemakaman Sultan Sulaiman secara adat dan menyerahkan prosesi itu kepada Bupati Deli Serdang, Munar S. Hamidjojo yang memimpin upacara pemakaman Sultan Serdang secara militer. 
Dari rangkaian keterangan Tengku Luckman Sinar, sisa utang Serdang yang berjumlah kira-kira satu juta gulden pada Kutai itu baru dapat dilunasi pada 1963, tiga tahun setelah Anwar meninggal dunia. Namun jabatan Sultan Serdang sempat kosong selama 35 tahun karena beberapa hal. Negeri ini kembali memiliki sultan definitif pada 1998 dengan penabalan Tengku Abunawar Sinar, adik tiri Anwar sekaligus kakak kandung Tengku Luckman Sinar sebagai Sultan Abu Nawar Sharifullah Alamshah (1998-2002).

"Penataan" yang sesungguhnya meminjam tari gubahan Sauti untuk membangkitkan batang terendam di Istana Serdang ini menjadi pangkal permasalahan yang melingkupi tari ini sampai kini. Pihak Istana terkesan memberikan pembatasan terutama tentang bagaimana seharusnya Serampang XII dilenggangkan di hadapan penonton. Belakangan, sejak tari ini mulai populer entah mengapa mulai muncul anggapan serius mengenai siapa yang lebih berhak menampilkan tarian lincah itu di panggung besar. "Penataan" oleh istana itu sesungguhnya tidak benar-benar terjadi, tetapi rumor penataan itu terlanjur membentuk sentimen yang membelah orientasi murid-murid Sauti yang turut mengembangkan tari pergaulan itu sejak periode awal dalam dua kelompok besar, yaitu kelompok penari dari kalangan bangsawan Melayu dan kelompok penari dari kalangan rakyat biasa. Pembagian ini secara langsung maupun tidak langsung membentuk sentimen di antara dua kelompok itu.

Sejak popularitas tari yang dikembangkan dari ronggeng ini meningkat selama 1949-1954, satu persatu masalah mulai timbul. Cerita "penataan" oleh istana agar selaras dengan adat resam kerap diungkit meskipun dalam pandangan muridmurid Sauti sama sekali tidak tampak ada perubahan dari "penataan" itu. Pandangan mengenai penataan ini juga terlihat dari sikap Tengku Radjih Anwar atau disapa dengan sebutan Tengku Mahkota ini yang menyatakan hanya meneruskan langkah pembakuan Serampang XII yang sudah dilakukan Sauti. Tengku Mahkota hanya melakukan konsensus agar agar tari pergaulan muda-mudi Melayu itu harus selalu selaras dengan adat resam Melayu. Oleh sebab itu, geri ronggeng yang melandasi tarian itu tidak boleh dilenggangkan secara berlebihan.

Inilah sebab tidak pernah timbul permasalahan langsung antara Sauti dan Anwar, tetapi penataan Anwar ini terlanjur membentuk pandangan muridmurid Sauti dari kalangan biasa terhadap murid-murid Sauti dari kalangan bangsawan Serdang, apalagi secara historis dan kultural, produk kesenian Melayu itu bukanlah milik istana melainkan berkembang di tingkat kawula Melayu lalu dibawa ke istana.

Permasalahan antara Sauti dengan Orang Kaya (OK) Adram mulai mencuat ketika Serampang XII mulai dikenal luas dan diminati meskipun ada 
keterangan bahwa masalah itu sudah sejak lama timbul di antara keduanya. Masalah antara Adram dan Sauti timbul karena keduanya berbeda pandangan mengenai bagaimana seharusnya atau sebaiknya Serampang XII ini dikembangkan. Sauti terutama karena profesinya sebagai guru cenderung memilih jalan untuk mengembangkan tari itu kepada siapa pun yang hendak menari tanpa harus memandang minat, bakat, kemampuan, dan kualitas teknik mereka yang ingin melenggangkan Serampang XII yang sedang digemari. Soal teknik dan mutu gerak, Sauti berpendapat dapat diperbaiki seiring dan setelah tarian itu dikenal luas oleh masyarakat. Sedangkan Adram berkeinginan sebaliknya.

OK Adram ini seorang Melayu terpelajar yang berprofesi sebagai pengacara. Ia diceritakan sebagai sosok laki-laki Melayu yang gagah. Profesinya sebagai pengacara mengesankan ia seorang laki-laki maskulin. Seperti laki-laki Melayu yang menaruh perhatian dan menggeluti kesenian ia dikenal pandai meronggeng, bersilat juga cakap membicarakan kesenian juga kebudayaan. Oleh karena kepandaiannya itulah, Adram didaulat sebagai pasangan menari Sauti ketika menampilkan Serampang XII untuk pertama kalinya dalam acara "Muziek en Toneel Vereeniging Andalas" di Grand Hotel Medan pada 9 April 1938 (Sinar 1977:65).
Waktu tari itu ditampilkan pertama kali di hadapan publik, Adram menjadi penari laki-laki sedangkan Sauti mengisi peran penari perempuan. ${ }^{7}$ Masa itu melenggangkan tari secara berpasangan di panggung terbuka untuk pertunjukan dengan lawan jenis tidak biasa dilakukan kecuali di gelanggang ronggeng yang biasa digelar dalam acara perkawinan. Di perhelatan ini siapapun boleh berpartisipasi. Ini pula alasan kuat mengapa Serampang XII yang digubah dari ronggeng itu dibawakan oleh Adram dan Sauti.

Posisi Adram dan Sauti di panggung perdana Serampang XII ini, secara langsung maupun tidak menunjukkan perbedaan karakter dua orang Pantai Cermin yang bersahabat ini dalam melenggangkan ronggeng gubahan itu. Jika Adram dikesankan maskulin, maka Sauti sebaliknya. Sauti yang bertubuh tinggi semampai menunjukkan ciri guru tipikal; lembut tutur katanya, tenang pembawaannya, perhatian, lebih banyak mendengar dan sabar (Meuraxa 1956).

Mengenai bagaimana tari Serampang XII dikembangkan, Adram yang secara adat berstatus Orang Kaya (dilafalkan: ohrangkaye atau rhangkaye) salah satu gelar dengan status sosial lebih tinggi dari kawula, merasa memiliki kewajiban kultural untuk menjaga segala tradisi yang dilangsungkan orang Melayu agar adat istiadat resam dan marwah puak

7 Wawancara, Yose Rizal Firdaus, Medan, 10 Maret 2012. 
Melayu senantiasa terjaga hingga ke generasi baru.

Inilah alasan mengapa Adram terlihat kaku dan selalu memberi tekanan kuat bahwa setiap calon penari maupun penari Serampang XII harus memahami teknik dasar ronggeng atau teknik tari Melayu lainnya sehingga Serampang XII yang lincah itu harus ditampilkan dengan baik dan prima. Ia menekankan pula bahwa terdapat jelas perbedaan teknik, posisi tubuh, dan cara menarikan Serampang XII antara penari laki-laki dan perempuan. "Bukan begitu lelaki menari!"8, begitu bentakan Adram kepada penari laki-laki yang terkesan melenggangkan langkah maupun geri tari Melayu dengan gemulai.

Prinsip dan pandangan Adram ini punya alasan kultural-empirik. Dalam ragam perkembangan kesenian Melayu, laki-laki yang ingin mahir melenggangkan gerakan ronggeng terlebih dahulu harus belajar silat. Kewajiban ini dimaksudkan untuk memberikan perbedaan tegas antara gerak tari laki-laki dan perempuan. Gerakan silat akan membuat geri lakilaki tampak bertenaga dan jelas seperti jurus-jurus silat. Sementara itu, gerakan perempuan yang halus, lembut, dan gemulai dipandang sebagai sesuatu yang kodrati, melekat sebagai citra diri sekaligus menjadi sifat perempuan.

Perbedaan pandangan antara Sauti dan Adram ini meskipun keduanya

\footnotetext{
${ }^{8}$ Wawancara, Yose Rizal Firdaus, Medan, 10
} Maret 2012. terkesan berhadap-hadapan tetapi tidak mengganggu perkembangan Serampang XII secara langsung. Namun masalah yang agak serius antara keduanya justru muncul setelah keduanya tiada. Beberapa seniman menyiarkan berita bahwa Adram-lah yang sesungguhnya menciptakan Serampang XII itu. Dalam narasi yang agak berbeda disebutkan bahwa tari gubahan Adram-lah Serampang XII yang asli (gubahan orisinal Adram) sedangkan Serampang XII yang populer itu dan dikenal sampai kini telah mengalami penyesuaian.

Namun penggiat kebudayaan Melayu memilih mengacuhkan hal itu hingga klaim yang digadang-gadang oleh segelintir seniman itu tidak lagi pernah didengar. Sauti disebutkan mengetahui bahwa pasangan menarinya itu juga menggubah ronggeng tetapi bukan Serampang XII. Beberapa seniman menyebut tari gubahan Adram itu mirip Serampang XII meski klaim kemiripan ini selalu dibantah apalagi dinamai Serampang XII (Nurwani 2003:53).

Nama Serampang ini tidak terkait sama sekali dengan kata serampangan. Kata serampang yang digunakan sebagai nama tari pergaulan ini berasal dari nama alat penangkap ikan penduduk Melayu yang ujungnya berupa mata tombak bermata tiga dengan pengait pada mata bilah sebelah kiri dan kanan. Serampang ini biasa digunakan untuk berburu ikan ukuran sedang yang mencari makan atau tersesat hingga ke pinggir sungai atau 
pantai dengan cara dilesakkan cepat agar ikan tertusuk. Penggunaan kata serampang dikaitkan dengan rentak tari yang cepat dan usaha menggapai cinta sejati. Pemberian tanda numerik Rumi (kadang ditulis juga dengan angka 12 atau ditulis dua belas) menunjukkan dua belas tahapan atau langkah dalam tari yang diiringi alunan musik hidup khas Melayu tanpa lantunan syair dan nyanyian.

Serampang XII mengisahkan proses membangun cinta suci pasangan pemuda-pemudi sejak pandangan pertama yang diakhiri dengan akad nikah dan peresmian perkawinan, persetujuan orang tua dan keluarga (Sinar 2011:86). Falsafah, nilai dan norma Melayu yang mengatur hubungan antara dua remaja yang saling jatuh cinta terpantul dari rangkaian gerak tari ini. Tempo musik yang cepat, dua kali lebih cepat dari tempo musik pengiring Pulau Dua, salah satu tari Melayu dari Sumatra Timur berentak cepat pun merepresentasikan hasrat remaja yang menggebu-gebu.

Popularitas Serampang XII bermula ketika Presiden Sukarno mengunjungi Medan untuk meresmikan beberapa proyek pembangunan di Sumatra Utara, termasuk peletakan batu pertama kampus Universitas Sumatra Utara (USU) pada 1951 (So'uyb 1989:58). Serampang XII tampil dalam salah satu acara peresmian di Medan meninggalkan kesan pada Sukarno juga Ibu Negara, Fatmawati. Pada tahun itu juga Sauti yang mendampingi para penari pada saat peresmian kampus USU itu diundang ke Jakarta untuk menunjukkan tari itu di Istana Negara sekaligus memberi tutorial sekaligus praktik ringkas melenggangkan Serampang XII secara langsung pada Fatmawati, Rahmi Hatta, dan sejumlah istri pejabat tinggi negara. ${ }^{9}$

Dalam praktik tari hari itu dan beberapa latihan sesudahnya, pasangan Fatmawati adalah Joop Ave, Menteri Pariwisata, Pos, dan Telekomunikasi (1993-1998). Kala itu, Joop menjadi Kepala Juru Masak Istana. Menurut Firdaus, Joop memang dipilih Sukarno untuk mendampingi Fatmawati. ${ }^{10}$ Sukarno yang pencemburu itu tidak ingin melihat Fatmawati menari berpasangan di depan umum dengan laki-laki yang tidak dikenalnya.

Masa itu, Sukarno yang mulai mengembangkan gagasan dekolonisasi dan merumuskan konsep Kebudayaan Nasional giat menghimpun berbagai kesenian daerah yang menunjukkan ciri nasional yang kelak dirumuskan sebagai bagian dari "puncak-puncak kebudayaan daerah" yang membentuk definisi kebudayaan nasional. Ragam

9 Wawancara, Makmur Sautim, Medan, 4 Maret 2012.

10 J. Anto, "Daya Tarik Serampang 12". Diunduh tanggal 10 November 2019 (https:/ /analisadaily.com/berita/arsip/2018/4/15/ 538476/daya-tarik-serampang-12/). Mengenai Joop Ave sebagai orang kepercayaan Sukarno ini juga disebutkan oleh Petrik Matanasi, "Sejarah Hidup Joop Ave, Orang yang Dipercaya Sukarno dan Soeharto". Diunduh tanggal 11 Maret 2020 (https://tirto.id/sejarah-hidup-joop-aveorang-yang-dipercaya-sukarno-soehartodfmU). 
kesenian dari seluruh daerah di Indonesia itu dihimpun, dikembangkan, dan diproyeksikan untuk menggantikan produk kesenian Barat, mulai dari musik ngak-ngik-ngok, yang merujuk pada rock and roll, hingga dansa Barat yang hendak dienyahkan Sukarno.

Pada 1954, Sauti memimpin satu tim kesenian dari Sumatra Utara yang merupakan bagian dari rombongan Misi Kebudayaan Indonesia ke Beijing. Di kota inilah, untuk pertama kalinya, secara resmi membawa misi negara, Serampang XII dari Serdang itu tampil di panggung internasional. Sesudah kelompok tari Sauti tampil di panggung, Sauti lalu didaulat memberikan pelatihan tari pergaulan Melayu ini dalam satu lokakarya di Akademi Tari Beijing (Nurwani 2003; So'uyb 1989).

Sesudah 1954 itu, gairah mempelajari Serampang XII gubahan Sauti itu menjalar luas ke seluruh negeri. Sayembara pada setiap jenjang mulai digelar untuk memilih raja dan ratu Serampang XII. Gairah itu makin kuat setelah tari ini ditetapkan sebagai tari nasional bersama Lenso dari Ambon yang dilenggangkan dengan iringan lagu "Waktu Hujan Sore-sore".

Namun di antara gairah baru belajar Serampang XII itu, sentimen yang muncul akibat penataan oleh Anwar lima tahun lalu muncul lagi. Sentimen ini lebih disebabkan oleh keterbatasan akses atas misi kebudayaan, jaringan, dan kesempatan yang tidak dimiliki kelompok murid Sauti dari kalangan rakyat biasa. Di masa puncak popularitas Serampang XII itu, siapapun penari atau kelompok tari ingin terlibat dalam pertunjukan besar seperti turut dalam Misi Kebudayaan Indonesia, tetapi peluang terbatas atau dibatasi oleh persyaratan yang tidak gampang.

Di sinilah murid Sauti dari kalangan bangsawan lebih unggul. Kemampuan keuangan yang memadai ditambah akses yang terbuka pada lembaga pemerintah membuat peluang tampil murid Sauti dari kelompok ini lebih terbuka. Kemampuan keuangan yang membuat kelompok ini selalu siap sedia dengan ketentuan yang digariskan seperti memesan setelan pakaian menari komplit dari bahan tekstil terbaik.

Hal ini berbanding terbalik dengan murid Sauti atau penari dari kalangan "miskin" yang agak kesulitan memenuhi ketentuan yang digariskan. Kebanyakan kelompok itu tidak mampu untuk mendapatkan atau membeli baju gunting Cina berbahan katun halus, songket untuk sampin, dan tengkuluk ataupun kain sutra untuk baju kurung dan selendang. Kemampuan murid Sauti dari kalangan ini tidak cukup memadai untuk memperoleh barang-barang yang terkadang harus didapatkan di pasar gelap. Harga songket, sutra maupun bahan tekstil terbaik yang harus diselundupkan dari Singapura itu tidak dapat dijangkau. Hal ini membuat penampilan muridmurid dari kalangan biasa di panggung nasional dan internasional jauh lebih rendah meskipun kualitas teknik 
menari mereka dapat disejajarkan atau bahkan lebih baik dibanding dengan penari dari kalangan bangsawan atau anak pejabat yang disisipkan ke dalam misi.

Soal peluang tampil di atas panggung nasional maupun dunia ini, langkah Sauti selaras dengan Anwar. Kepala Rumah Tangga Kesultanan Serdang yang juga seniman ini telah mendorong dan menyokong Tengku Nazly salah satu putrinya untuk mendirikan sanggar Nazly Group Medan. Empat penari Nazly Group yang berguru pada Sauti yaitu Tengku Luckman Sinar (adik Anwar), Tengku Nazly, Tengku Zahyar (keduanya anak Anwar) dan Arifin Nasution (menantu Anwar, suami Tengku Zahyar) inilah yang menampilkan Serampang XII untuk pertama kali di panggung dunia dalam misi resmi pertama ke Beijing (Lindsay 2011b:230). Sauti turut mendampingi kelompok ini menjalani tur selama tiga bulan di Moscow (Uni Soviet), Warsawa (Polandia), Beijing (RRT) dan Ulaanbaatar (Mongolia). ${ }^{11}$

Penampilan Nazly Group dalam misi kebudayaan perdana ini memacu perkembangan baru Serampang XII di Indonesia. Penetapan tari ini sebagai tari nasional membuat tari ini diajarkan secara luas. Boleh dibilang seluruh sanggar, kelompok kesenian, termasuk

\footnotetext{
${ }^{11}$ Wawancara, Tengku Daratul Qamar, Medan, 6 Maret 2012. Keterangan ini selaras dengan hasil wawancara Tengku Luckman Sinar, Sou'yb yang mewawancarai Tengku Sittta Syaritsa, keterangan Yose Rizal Firdaus serta gambar sampul jurnal Indonesia.
}

unit kegiatan mahasiswa bidang kesenian di perguruan tinggi di Indonesia, menjadikan Serampang XII sebagai tari wajib. Perkembangan pesat tari pengganti dansa itu mendorong pemerintah menggelar Sayembara Nasional Tari Serampang XII di Jakarta pada 1959 dilanjutkan pada 1960 di Surabaya dan sayembara pamungkas yang berakhir ricuh pada 1963 di Medan.

Kericuhan yang terjadi di Medan ini merupakan akumulasi dari sederet masalah serius yang mendera penggiat dan lingkungan Serampang XII sebelum tari ini berada pada masa keemasannya. Masalah "penataan" dan kualitas teknik menari yang belum tuntas ditingkatkan merupakan masalah utama.

Masalah serius lain ialah Serampang XII ini terlanjur dipandang sebagai hiburan yang "disamakan" dengan ronggeng dan sudah disebut ronggeng pula. Pada dasarnya, tari ini memang diadaptasi dari ronggeng Melayu yang sering ditampilkan dalam acara daur hidup untuk menghibur undangan. Pergeseran ini, meskipun dipandang sebagai bagian dari perkembangan telah membuat tari yang menurut Adram harus ditampilkan dengan prima sudah mengalami kemunduran teknik. ${ }^{12}$ Para penari dianggap tidak lagi menarikan

\footnotetext{
${ }^{12}$ Mujabir, Adi, "Mahakarya dari Perbaungan Bernama Serampang XII". Diunduh 29 Nopember $2011 \quad$ (http:// perbaungan.blogspot.com/2012/01/ mahakarya-dari-perbaungan-bernama.html).
} 
berdasarkan teknik baku tetapi peniruan sehingga khalayak cenderung menyamakan Serampang XII dengan ronggeng.

Kemunduran tari yang sudah menjadi mercu tanda Melayu dan Provinsi Sumatra Utara ini, Serampang XII justru terjadi di tengah popularitas tari itu. Bukan sebagai pergaulan mudamudi Indonesia sebagaimana yang diinginkan Presiden Sukarno tetapi sebagai tari hiburan yang ditonton.

Menurut Jose Rizal Firdaus popularitas Serampang XII tidak diikuti transformasi kualitasnya. Artinya, transformasinya terjadi hanya pada bentuknya saja, bukan kepada tekniknya. ${ }^{13}$ Satu masalah lain dari perkembangan pesat tari ini ialah pendangkalan teknik menari. ${ }^{14} \mathrm{Hal}$ ini disebabkan, orang-orang dari luar Serdang yang melenggangkan tari ini tidak lagi didukung oleh pengetahuan dan penguasaan terhadap falsafah, nilai, dan teknik tari yang dibakukan. Akibatnya terjadi pergeseran pandangan bahwa tari ini tidak lebih sebagai tari pertunjukan untuk menghibur penontonnya.

Pun demikian dengan pengetahuan tari. Pola, gerak, dan teknik dasar Serampang XII seperti lentik, kuntum, jendit, kerling, langkah celatuk,

${ }^{13}$ Wawancara, Yose Rizal Firdaus, Medan, 10 Maret 2012.

${ }^{14}$ Ahmad Salehuddin. "Serampang Duabelas: Tari Tradisional Melayu Kesultanan Serdang Sumatra Utara”. Diunduh 13 Februari 2012 (https://asalehudin.wordpress.com/2009/04/ 25/serampang-duabelas-tari-tradisionalmelayu-kesultanan-serdang-sumatra-utara/). goncek, meniti batang, lonjak, singsing, ayam patah atau siku keluang tidak lagi diajarkan bersama falsafah dan nilainya atau dipraktikkan secara prima sebagaimana digariskan Sauti dalam risalahnya juga pernah ditegaskan Adram secara verbal pada Sauti.

Masa itu, sekalipun banyak masalah yang muncul mengiringi popularitas Serampang XII, Sauti tetap menjadi sosok yang dirujuk dan paling identik dengan Serampang XII. Para penari dari DKI Jakarta, Jawa Barat, Jawa Timur, Sulawesi Selatan, Kalimantan Barat serta Selatan, Malaya (Malaysia dan Singapura) dan Hongkong memastikan bahwa Sautilah sosok utama di balik Serampang XII yang di Singapura dilenggangkan dengan iringan lagu "Burung Nuri".

Sauti meninggal dunia di Perbaungan pada 21 Agustus 1963 setelah menunaikan tugas menyebarluaskan Serampang XII tetapi belum sempat "meluruskan" kekeliruan teknik akibat penyebarluasan tari itu sebagaimana pernah disampaikan Sauti kepada Adram. ${ }^{15}$ Sauti dimakamkan di samping makam ibunya di halaman Mesjid Raya Sulaimaniyah Perbaungan yang merupakan Kompleks Pemakaman Diraja Serdang.

\footnotetext{
15 Wawancara, Yose Rizal Firdaus, Medan, 10 Maret 2012 dan J. Anto, "Daya Tarik Serampang 12". Diunduh tanggal 10 November 2019 (https://analisadaily.com/berita/ arsip/2018/4/15/538476/daya-tarikserampang-12/).
} 
Sauti meninggalkan seorang istri, Syahridjat (1912-1998) putri Kopral Bakir salah satu opas Istana Serdang, juga bekas murid Sauti yang dinikahinya, ketika perempuan yang dibesarkan Sersan Senen atasan ayahnya itu berusia tujuh belas tahun. Dari perkawinannya dengan Syahridjat, Sauti memperoleh sebelas orang anak, enam orang laki-laki dan lima perempuan. Anak-anak tertua Sauti mewarisi bakat dan mendapat bimbingan langsung dari sang ayah. Kini, dari sebelas orang anak Sauti itu empat orang di antaranya masih hidup. Salah satu anaknya itu, Akhiruddin Sauti terlibat aktif dalam kegiatan Majelis Adat Budaya Melayu Indonesia (MABMI) Kabupaten Serdang Bedagai.

Pada tahun ketika Sauti meninggal, Sayembara Tari Serampang XII Tingkat Nasional digelar di Medan. Sayembara yang ketiga kali ini merupakan bentuk dukungan Presiden Sukarno kepada tari yang dilenggangkan dengan rentak cepat sebagai tindak lanjut penyebarluasan tari ini ke seluruh Indonesia.

Sayembara di Medan berakhir ricuh. Kericuhan ini terjalin berkelindan dengan hal yang pernah jadi masalah sebelum ini. Masalah itu menimbulkan perbedaan penilaian atas teknik dasar tarian yang memang menjadi perdebatan jauh sebelum sayembara ini digelar. Beberapa gerakan atau sikap tari, seperti mengangkat seluruh jari sehingga tapak kaki dapat dilihat penonton dianggap tidak pantas dilakukan sehingga menurut kalangan bangsawan hal itu harus disesuaikan.

Hal ini tidak diterima oleh sebagian murid dan/atau penari dari kalangan umum yang mempelajari tari Serampang XII apa adanya dari Sauti. Dalam sayembara terakhir itu, seorang anggota TNI yang menjadi pendamping kontingen Urusan Moril Korps Ajudan Jenderal Komando Daerah Militer atau Uril Ajendam Siliwangi melepaskan tembakan ke udara karena tidak puas dengan keputusan juri yang memenangkan Tengku Danil beserta pasangan menarinya yang juga istrinya. ${ }^{16}$ Salah satu juri dalam sayembara bergengsi itu adalah Tengku Osman yang juga bangsawan Deli.

\section{Sauti dan Kebangkitan Melayu di Sumatra Utara}

Sauti dan Serampang XII dapat 'didaulat' sebagai penawar duka orang Melayu Sumatra Timur yang mengalami kemunduran politik sejak kemerdekaan. Pada tahun 1946, kerajaan-kerajaan Melayu termasuk Karo dan Simalungun lenyap ditelan Revolusi Sosial yang berlumuran darah (Reid 1987:356-366). Para Sultan dan raja-raja yang menjadi simbol kemelayuan sekaligus tumpuan kebudayaan dan struktur masyarakat Melayu juga lenyap (KathiritambyWells and Villiers 1990:7). Cerita tentang kemakmuran dari perkebunan ketika provinsi ini menjadi bagian utama dari Negara Sumatra Timur

${ }^{16}$ Wawancara, Yose Rizal Firdaus, Medan, 10 Maret 2012. 
(NST) yang berhasil menghimpun aristokrat Melayu, Karo dan Simalungun dalam satu dari 15 negara bagian pada masa Republik Indonesia Serikat pun tidak berbekas lagi.

Demikian pula dengan cerita seputar Barisan Pengawal Negara Sumatra Timur (BP-NST) yang terkenal dengan nama lebih dikenal sebagai Blauwpijper yang diperkuat persenjataan modern, personilnya pun digaji lebih tinggi dari anggota TNI. Pengalaman selama NST (1947-1950) justru menjadi senjata bagi musuh-musuh politik orang Melayu, Karo dan Simalungun untuk menekan kelompok etnik asli ini (Suprayitno 2001:181-89).

Awal tahun 1950-an kemunduran orang Melayu berlanjut ketika orang Batak dari pedalaman Tapanuli datang bergelombang ke Sumatra Timur (Castle 2001; Cunningham 1958). Di daerah dataran rendah bertanah subur ini, orang Batak yang menganut Kristen secara sistemik mencaplok tanah-tanah milik orang Melayu. Konflik antar-dua kelompok etnik ini memiliki akar yang panjang jika dikaitkan dengan gagasan bumiputra dan keagamaan (Perret 2010:345-48). Oleh karena itu ketika keduanya bersinggungan konflik terbuka tidak dapat dielakkan dan berhasil menarik kelompok etnik yang menganut Islam (Mandailing, Angkola, Minangkabau dan Jawa) ke gelanggang konflik.

Secara statistik, orang Batak berhasil memenangkan perebutan itu dengan banyaknya tanah-tanah orang Melayu yang dapat dikuasai. Orang
Batak mengembangkan cara paling efektif dengan melepaskan babi peliharaan di tanah-tanah yang ingin mereka kuasai. Dengan demikian, orang Melayu yang menganggap tanah mereka tercemar pun meninggalkan tanah itu (Cunningham 1958).

Rentetan peristiwa itu menempatkan orang Melayu lemah secara politik dibanding kelompok etnik lain. Kebangkitan aktivitas kesenian Melayu setidak-tidaknya menjadi dorongan untuk membangkitkan identitas Melayu yang masa itu identik dengan keterbelakangan. Di Medan, ibu kota Sumatra Utara yang belum sepenuhnya pulih akibat pemberontakan perwira TNI yang bergabung membentuk PRRI dan kisruh nasionalisasi, Orkes Melayu (OM) dan sanggar tari pun tumbuh pesat menyusul Roman Pitjisan dan/ atau Sastra Medan yang telah menjadi bagian dari budaya pop yang lebih dahulu populer. Sejumlah pencipta lagu, penyanyi dan kelompok OM terkemuka lahir dan menjadi mercu tanda lain bagi kota perkebunan ini, antara lain seperti Nasir, Nur Ainun, Zaidar, Lili Suhairi, Rubiah, Orkes Melayu Studio Medan, Sukma Murni, Budi Pekerti dan Rayuan Kesuma. Demikian pula film dan bintang film, antara lain Ahmad Awab Aziz alias Ahmad C.B. (singkatan dari 'Cas Bara') aktor keturunan Arab dan Kasma Booty yang berayah Belanda, berkarir sezaman dengan aktor Malaya terkemuka, P. Ramlee (Plomp 2011:425-31). 
Dinamika kebudayaan masa itu terutama karena ada dukungan pemerintah berhasil mendorong orang Melayu untuk turut serta dalam kegairahan itu. Kegairahan itu diwakili oleh tari Serampang XII dan sosok Sauti yang sabar. Serampang XII sebelum digubah telah dikenal dengan nama tari Pulau Sari yang merupakan penyingkatan kalimat 'di pulau sehari'. Peningkatan tempo musik dan rentak tarian menjadi hal paling penting sehingga tari pulau Sari yang diiringi lagu Cerencang diubah namanya menjadi Serampang XII. Istilah 'serampang' memang tidak memiliki sangkut paut dengan tari-menari tetapi digunakan Sauti untuk menunjukkan perbedaan mendasar dengan tari Pulau Sari, Lagudua atau ronggeng Melayu yang bebas dilenggangkan (Sinar 2011:86).

Hingga penghujung hidupnya, Sauti memilih bertahan dengan tetap tinggal di Perbaungan, kota yang menumbuhkan bakatnya. Setiap hari hingga pensiun Sauti menumpang kereta api pertama ke kantornya di Medan. Selama itu pula Sauti mencurahkan sebagian besar waktunya untuk mendokumentasikan semua karyanya hingga tersusun buku teknik dasar pembelajaran delapan tari legendaris yang ia gubah. Sauti memang belum sempat 'meluruskan' atau menata kembali tari yang dikembangkannya hingga mencapai puncak popularitasnya itu secara langsung, namun buku yang disebarluaskan secara terbatas itu sesungguhnya merupakan bagian dari usaha mengembalikan teknik dan kualitas Serampang XII seperti yang diinginkan Adram ketika tarian itu melambungkan nama Sauti sebagai maestro tari terkemuka dari Sumatra Utara.

\section{SIMPULAN}

Masa kini, Serampang XII diwariskan kepada Lembaga Studi Tari Patria (berdiri 1979) secara genealogis dan Sanggar Sinar Budaya Group (2001) secara ideologis. Kedua lembaga ini menjadi these atas permasalahan yang terjadi 70 tahun lalu antara Sauti dan Anwar, yang sesungguhnya bukan masalah, serta antara Sauti dan Adram. Sinar Budaya Group dapat disebut sebagai genesis dari Nazly Group dan kelompok-kelompok kesenian yang lahir dan berkembang di tangan para bangsawan Serdang. Patria yang sempat mendirikan dan mengelola Sekolah Menengah Kesenian di Tanjung Morawa merupakan perwujudan keinginan murid-murid Sauti dari kalangan biasa yang menunjukkan tradisi berkesenian Melayu yang berasal dan berkembang di masyarakat bukan di istana. Patria juga memiliki kewajiban untuk mengemban tugas "meluruskan" tari yang belum sempat dilakukan Sauti.

Kisah tentang Sauti belum pernah dituliskan meskipun ia memperoleh kedudukan istimewa sebagai maestro dalam karirnya. Apalagi, Sauti dan Serampang XII ibarat dua sisi mata uang yang tidak dapat dipisahkan. Sauti 
pun merupakan maestro terakhir dalam perkembangan seni pertunjukan kontemporer di Serdang yang telah berlangsung sejak akhir abad ke-20 hingga masa pendudukan Jepang. Kegiatan kesenian di Serdang berjalan perlahan sejak Revolusi Sosial karena negeri itu terpuruk secara politik. Ketiadaan mecenas yang kuat secara ekonomi dan politik sebagaimana Sultan Sulaiman Shariful Alamshah di masa lalu juga berperan besar dalam kemunduran sehingga memaksa para seniman dari Serdang beralih pekerjaan menjadi pekerja kesenian yang pindah ke kota-kota besar (terutama Medan).

\section{E. UCAPAN TERIMA KASIH}

Terima kasih kepada Sultan Kerajaan Negeri Serdang, Tuanku Luckman Sinar Basarshah II (1933-2011), Potret Sultan Serdang ini bersama tiga penari Nazly Group pernah digunakan sebagai gambar sampul jurnal Indonesia Universitas Cornell. Terima kasih juga kami sampaikan kepada Yose Rizal Firdaus, Yuzli Yar, Kartini Souyb dan Lembaga Seni Tari Patria yang menjadikan sembilan tari Melayu karya Sauti sebagai adikarya. Juga kepada Makmur Sauti, S.P. Dewi Murni, Ratna M.S., Nazief Chatib, Indera Afkhar, Suprayitno, M. Affan dan Tengku Mira Sinar, serta segenap pihak yang menyokong penelitian dan rekonstruksi kisah hidup Sauti ini.

\section{DAFTAR SUMBER}

Agustono, Budi. 1993. Kehidupan Bangsawan Serdang 1887-1946.
Tesis, Prodi Sejarah, FIB, Universitas Gadjah Mada.

Andaya, Leonard Y. 2006. "The Search for the 'Origins' of Melayu." Pp. 315-30 dalam Contesting Malayness Malay Indentity Across Boundaries, disunting oleh T. P. Barnard. Singapore: National University of Singapore Press.

Asnan, Gusti. 2007. Memikir Ulang Regionalisme Sumatera Barat Tahun 1950-An. Jakarta: Yayasan Obor Indonesia \& KITLV Jakarta.

Bahar, Saafroedin. 2018. Etnik, Elite dan Integrasi Nasional: Minangkabau 1945-1984, Republik Indonesia 1985-2015. Yogyakarta: Gre Publishing.

Breman, Jan. 1997. Menjinakkan Sang Kuli: Politik Kolonial, Tuan Kebun, dan Kuli di Sumatra Timur pada Awal Abad Ke-20. Jakarta: Pustaka Utama Grafiti.

Castle, Lance. 2001. Tapanuli 19151940: Kehidupan Politik Suatu Karesidenan di Sumatra. Jakarta: Kepustakaan Populer Gramedia.

Cribb, Robert Bridson. 1990. Gejolak Revolusi di Jakarta 1945-1949: Pergulatan Antara Otonomi dan Hegemoni. Jakarta: Grafiti.

Cunningham, Clark E. 1958. The Postwar Migration of Toba-Bataks to East Sumatra. New Haven.

Hamdani, Nasrul. 2011. "Ronggeng, Brass Band dan Seri Indera Ratu: Perkembangan Seni Pertunjukan 
Kontemporer di Serdang 18891942." Jurnal Sejarah No. 2:26-33. 2012. "Bangsawan, Sejarawan dan Budayawan: Biografi Ringkas Tengku Luckman Sinar." Haba No. 61:46-52.

Kahin, Audrey. 2008. Dari Pemberontakan ke Integrasi, Sumatra Barat dan Politik Indonesia 1926-1998. Jakarta: Yayasan Obor Indonesia.

Kathiritamby-Wells, J., and John Villiers. 1990. The Southeast Asian Port and Polity: Rise and Demise. Singapore: Singapore University Press.

Kerkhof, Jasper Van Der. 2005. "Indonesianisasi of Dutch Economic Interests, 1930-1960 the Case of Internatio." Bijdragen Tot de Taal-, Land- En Volkenkunde 161(2-3):181-209.

Kleden, Ignas. 1987. Sikap Ilmiah dan Kritik Kebudayaan. Jakarta: LP3ES.

Klinken, Gerry van. 2007. "The Combative 'I': State Domination and Indonesian Self-Writing. "The Journal of Life Writing Vol. 4:197-214.

Kuntowijoyo. 2003. Metodologi Sejarah. Yogyakarta: Jurusan Sejarah FIB UGM dan Tiara Wacana.

Lindsay, Jennifer dan Maya H. T. Liem (eds.). 2011. Ahli Waris Budaya
Dunia: Menjadi Indonesia 19501965. Jakarta \& Denpasar: Pustaka Larasan \& KITLV Jakarta.

Lindsay, Jennifer. 2011a. "Ahli Waris Budaya Dunia 1950-1965: Sebuah Pengantar." Hlm. 1-28 dalam Ahli Waris Budaya Dunia, Menjadi Indonesia 1950-1965, disunting oleh Lindsay, Jennifer dan Maya H. T. Liem. Jakarta \& Denpasar: Pustaka Larasan \& KITLV Jakarta. . 2011b. "Menggelar Indonesia di Luar Negeri." dalam Ahli Waris Budaya Dunia, Menjadi Indonesia 1950-1965, disunting oleh Lindsay, Jennifer dan Maya H. T. Liem. Denpasar: Pustaka Larasan \& KITLV Jakarta.

Meuraxa, Dada. 1956. "Sauti, Fred Astaire dari Serdang." Mimbar Umum, Syarahan Mingguan.

Moeljanto, D. S., Taufiq Ismail. 1995. Prahara Budaya: Kilas-Balik Ofensif Lekra/PKI dkk. Bandung: Mizan.

Nurwani. 2003. Serampang XII: Tari Kreasi Yang Mentradisi Pada Masyarakat Melayu Pesisir Sumatera Timur. Tesis, Prodi Seni Pertunjukan, Universitas Gadjah Mada.

Perret, Daniel. 2010. Kolonialisme dan Etnisitas, Batak dan Melayu di Sumatera Timur Laut. Jakarta: KPG-EFEO \& Puslitbang Arkenas. 
Plomp, Marije. 2011. "Pusat Roman Picisan dan Pusat-Pusat yang Lain: Kehidupan Budaya di Medan 19501958" dalam Ahli Waris Budaya Dunia, Menjadi Indonesia 19501965, disunting oleh Lindsay, Jennifer dan Maya H. T. Liem. Denpasar: Pustaka Larasan \& KITLV Jakarta.

Ratna, Nazief Chatib, Tengku Silvana Sinar, Nasrul Hamdani, SP Dewi Murni dan Indra Afkar. 2012. Perjuangan Sultan Sulaiman Shariful Alamshah dari Serdang (1865-1946) Penerima Bintang Mahaputera Adipradana 2011. Medan: Sinar Budaya Group.

Reid, Anthony. 1987. Perjuangan Rakyat: Revolusi dan Runtuhnya Kerajaan-Kerajaan di Sumatera. Jakarta: Sinar Harapan.

Ricklefs, M. C. 2005. Sejarah Indonesia Modern 1200-1900. Jakarta: Serambi Ilmu.

Simbolon, Parakitri T. 2007. Menjadi Indonesia. Jakarta: Kompas.

Sinar, Tengku Luckman. 1977. Pengantar Etnomusikologi dan Tari Melayu. Medan: Perwira.

Sinar, Tengku Mira. 2011. Teknik Pembelajaran Dasar Tari Melayu Tradisional, disunting oleh $\mathrm{M}$. al Mudra. Medan: Yayasan Kesultanan Serdang dan BKPBM Yogyakarta.
So'uyb, Kartini. 1989. Tari Serampang Dua Belas Karya Sauti Yang Ditata Dengan Akar Tari Melayu Sumatera Utara. Medan: Lembaga Studi Tari Patria.

Supartono, Alexander. 2000. Lekra vs Manikebu, Perdebatan Kebudayaan Indonesia 1950-1965. Skripsi, STF Driyarkara.

Suprayitno. 2001. Mencoba (Lagi) Menjadi Indonesia: Studi Tentang Negara Sumatera Timur 19471950. Yogyakarta: Tarawang.

Vickers, Adrian. 2008. "Mengapa Tahun 1950-an Penting Dalam Kajian Indonesia." dalam Perspektif Baru Penulisan Sejarah Indonesia, disunting oleh Henk Schulte Nordholt. Jakarta \& Denpasar: Yayasan Obor Indonesia.

Wawancara. Makmur Sauti. Medan. 4 Maret 2012.

Tengku Daratul Qamar. Medan, 6 Maret 2012.

Tengku Mira Sinar. Medan, 7 Maret.

Yose. Rizal Firdaus. Medan, 10 Maret 2012. 